\title{
CULTURAL GLOBALIZATION IN A CONTEST WITH THE STATE AND NATIONALISM
}

Ms. Samreen Bari, Research Scholars, Dept. of International Relations, University of Karachi

Ms.Sidra Ahmed, Research Scholars, Dept. of International Relations, University of Karachi

\begin{abstract}
What is globalization? It is difficult to define globalization with a single definition although it is a buzz word of this century; this term has mesmerized and fascinated the world significantly. It is considered as the large scale convergence process, it is a multidimensional phenomenon the main agent to activate the merger of economy and culture of the local and distant as a result growing interdependence in all walk of life is eradicating the cultural, social, territorial and religious barriers.
\end{abstract}

The advocates of globalization predict that that through this process poor or developing countries can improve their economies and can raise the standard of living of their common people while the opponents of globalization claim that uncontrolled or free international market economy is benefitting the multinational corporations mostly operated by the entrepreneurs of the western world at the expense of local businesses, local cultures and common people. The advancement of technology and free market economy are working together to create a new globalized and interconnected world. The dynamic and ever-changing technological revolution involving the creation of a computerized network of communication, transportations, and exchange the acceptance of a globalized economy, the enlargement of world capitalist market system is absorbing ever more areas of the world and orbit of production, exchange, and consumption. As the world is experiencing and exploring the massive waves of ideas, norms, values, beliefs and hard products through direct as well as indirect channels not only media but tourists, businessmen, NGO's, migrants are transferring their ideas, beliefs, and ideas from one part of the world to another. Social media is another medium contributing 
to enhance and promote the cultural globalization. Television channels especially Western television networks are playing with the minds of the masses of the world and are promoting their Western interests drastically. Undeniably realism provide and is enriched with theories to explain the world politics. It is clear now that as per realism the 'states' are the utmost honored players of realism but advocates of globalization stresses that the authority of states are constantly deteriorating because of the byproducts of globalization like transnational corporations, powerful regional and international institutions and due to the unofficial, un avoidable and un controllable transfer of ideas and Culture

Key Words: Globalization, Culture, Nation State, Territory, Nationalism

\section{INTRODUCTION:}

What is globalization? It is tough to explain the term globalization in a single definition though it is a buzz word of this period; this term has fascinated and captivated the world significantly. It is deliberated as the large scale merging process, it is a multidimensional phenomenon the key cause to galvanize the merger of economy and culture of the local and distant as an outcome growing interdependence in all walk of life is eliminating the cultural, social, territorial and religious barriers.

The merged yet conflicting, different at the same time conglomerate but distant societies can now easily interact and share their troubles, grieves, happiness, ideas, culture, technologies, social values, beliefs, religion and trade openly and deliberately without the involvement of Governments and formal institutions. The supporters of globalization expect that through this process poor or developing countries can escalate their economies and can raise the standard of living of their common people. While the opponents of globalization assert that free international market economy is benefitting the multinational corporations commonly operated by the entrepreneurs of the western world at the expense of local businesses, local cultures and common people. The improvement and advancement of technology and free market economy are working together to produce a 
new globalized and interrelated world. The vigorous and ever-changing technological revolution involving the formation of a computerized network of communication, transportations, and exchange the recognition of a globalized economy, the enlargement of world capitalist market system is captivating ever more areas of the world and orbit of production, exchange, and consumption. As the world is going through and exploring the enormous waves of ideas, norms, values, beliefs and hard products through direct as well as indirect channels not only media but tourists, businessmen, NGO's, emigrants are transporting their thoughts, beliefs, and philosophies from one part of the world to another. Social media is an added medium contributing to improve and promote the cultural globalization. Television channels specially Western television networks are playing with the minds of the masses of the world and are promoting and projecting their Western interests drastically.

Then the question arises whether these interdependencies and retrenchment of time and space due to the blessings of advanced, prompt and effective technological inventions are supporting the world humanity, economy and states evenly and without any discrimination, it is essential to examine the security, economic, cultural and social consequences of globalization on developed as well as on developing nations. Its plentiful arguable definitions can hardly answer the question. In view of numerous scholars globalization is dividing the world into two group winners and losers. In normative terms, some authors have linked, projected and fabricated 'globalization' as a synonym to growth, accomplishment, harmony, justice, equality, prosperity, and peace. For others, however, the word has fictitious distractions, it is blamable of creating anarchy, inequality, frustration, tragedy and trouble. For them, it is far from an identical, irreversible, and unstoppable propensity it would see as it is abolishing local cultures and widening inequality gaps, diminishing the spirit of Nationalism and is responsible for fading of nation state system. Globalization is an inconsistent, faulty, discontinuous contingent and in many ways contradictory and puzzling process. Increasing disparity is the most severe problem facing world society because essentially globalization is benefitting, endorsing and projecting the Westernization or Americanization throughout the globe. Western Intelligentsia plays a 
vibrant role in encouraging and in sustaining the projects that are advancing their objectives. It is carried out by various ways educational links, foundations, nongovernment organizations and organizations openly or indirectly connected to the government. The intelligentsia and its varied assisting agencies are spreading and promoting the ideas typically created and invented by the western philosophers and intellectuals.

Confusion on understanding of the meaning of globalization is not surprising. The word 'international' experienced a similar misunderstanding and misperception when it was suggested by Jeremy Bentham in the 1780 's, when people were not too much well conscious of the cross-border relationships between nation states.

Globalization can be described in several ways

o The strengthening of global interconnectedness.

o A process that promotes economic, political, and other cultural connections among people living all over the world.

o The world condition created by relatively recent developments in information, communication and transportation technologies.

o a process (or set of processes) which embodies a transformation in the spatial organization of social relations and transactions, generating transcontinental or interregional flows and networks of activity, interaction and power.

o Manfred B Steger (a professor of global studies at the Royal Melbourne Institute of Technology) declared it as a social process and used these words to define globalization:

'Globalization refers to multidimensional set of social processes that create, multiply, stretch and intensify worldwide social interdependencies 
and exchanges while at the same time fostering in people a growing awareness of deepening connections between the local and the distant'. (Steger, 2007)

o Walters defines it with fascinating words as 'A social process in which the constraints of geography on economic, political, social and cultural arrangements recede, in which people become increasingly aware that they are receding and in which they act accordingly". (Waters, 1995)

o Anthony Giddens explained globalization a process of decoupling or distanciation between space and time' he also adds a thought-provoking twist when emphasizing that globalization 'is a process of uneven development that fragments as it coordinates'. (Giddens, 1991)

o Jonathan Friedman proclaims that globalization is the invention of cultural fragmentation as much as it is the result of modernist homogeneity. (Freidman, july, 2014)

o British social theorist Martin Albrow argues that 'globalization is a transformation not a culmination and the transition to a new era rather than the apogee of the hold'. (Unesco.org, 2000)

o Cox writes about globalization that it produces a 'resurgent affirmation of identities'.(Unesco.org, 2000)

o David Harvey and James Mittleman observe globalization involves a 'compression' of space and shrinkage of the world. (social theory rewired, n.d.)

o Roland Robertson claims that globalization refers both to the solidity of the world and the intensification of consciousness of the world as whole. (Robertson, 1992) 
o Martin Albrow defines globalization as the 'diffusion of practices, values and technology that have an influence on people's lives world wide'. (Albrow, 1990)

o Mauro F Gullen : Globalization is also an ideology with multiple meanings and lineages .(Gullen, 2001)

o Gilpin recognizes globalization as "the enlargement of transnational spaces and actors, Dependent upon national authorities and the understood consent of nation states" (globalization, nation states and global governance)

o Appadurai's explanation and definition of globalization is entirely different as he sees it as the ever changing and "flowing" of technology, economy, media and ideology "ideology' through the movement of people over cultural and national boundaries. (Appadurai, 2010)

o Paul Hirst and Graham Thompson in Globalization in Question and Robert Wade in Globalization and its limits see it as feeble process. (Hirst \& Thompson, 1996)

o In an ideal world globalization is the by and large relation among states and merger of the dissimilar communities throughout the globe outcome in the origin of a single globalized and uniform community. 'With advances in technology and communications, the world becomes de territorialized' (Robertson, 1996).

o Mary Kaldor argues that globalization is a 'complex, contradictory process that actually involves both glocalization and localization, integration and fragmentation, homogenization and differentiation. (Kaldore, 1999)

o Ulrick Beck pointed out, globalization as a process "through which sovereign national states are crisscrossed and undermined by transnational 
actors with varying prospects of power, orientations, identities and networks." (Beck, 2000)

o Richard Langhorne describes globalization as the latest stage in ongoing transformations and accumulation of technological advances that have enabled people 'to conduct their affairs across the world without reference to nationality, government, authority, time of days or physical environment'. (Langhorne, 2001)

By concentrating on the definition presented by Roland Robertson, he used the word 'deterritorialization' that is again a questionable word. In western perception the space means grasping a place that can be calculable and extended but Robertson is demanding that now the territory is not the only political way to consider the land. The developing massive waves of globalization prove that the calculable insight of space has been elongated to the globe. Deterritorialization, considered a central feature of globalization, implies the growing presence of social forms of contact and involvement which go beyond the limits of a specific territory, a kind of "weighing of anchors" of social relations (Gidden's 1990), therefore, globalization is minimizing or is responsible to diminish and of rusting the spirit of Nationalism as per Garcia Canclini (Cancilini, 2014) the concept of Globalization constitute both sides of the same coin of cultural globalization. Deterritorialization in actual projected the concept of the loss of the "natural" relation between culture and the social and geographic territories (Garcia Canclini). We are experiencing that the culture is becoming more and more de territorialized and is absorbing and is being influenced and being penetrated by elements from other cultures. This ends in cultural contamination, cultural pluralism and hybridization. It is becoming more difficult to study culture of diffusion. Apart from it and at the same time, it is becoming more important to study it because of its massive influence on consumer behavior and its direct implications on security and on National character of the nations. As cultural globalization is providing and focusing on a network that is not dependent on traditional, political, economic, cultural and geographical boundaries. 


\section{STATE, CULTURE AND GLOBALIZATION IN REALIST PARADIGM STATE:}

The main and the principal concern of every shades of realist theorists arises with the examination of war and peace, the foundations and situations, the reactive and nonreactive policies, the consequences of actions and reactions and the control and intensification of power are their principal concerns. The theory of realism is very much focused on the state because the state is, undoubtedly, the key political unit in the international arena. Hence, realism is a political theory; or in other words it is a theory of the state. Realism is a theory that is accountable to split the world into two different domains. John J. Mearsheimer (II)1, 2006) described this philosophy in a very understandable manner:

'Realists start with the theory that states are the main actors on the world stage. They emphasize most of their attention on the great powers, however, because these states have the largest impact on what happens in international politics. Realists also emphasize that states operate in an anarchic system, which is not to say that the system is characterized by chaos or disorder. Anarchy is simply an ordering principle; it means that there is no centralized authority or ultimate arbiter that stands above states.'

Thus presence of conflict among states as per realists is a natural condition of the international order. The gist of Hans Morgenthau's theory is that states are by nature 'power maximizers'. Now, power represents 'anything that creates and upholds the control of man over man'. As every state define and plan its betterment in terms of the indefinite enrichment of its control, therefore either a state is intentionally a hunter or victim to any other state or nation. Hence this is the natural requirement of this tussle that, states must eventually look to self-help for their survival. Therefore, for existence of states and for the survival of the fittest E. H. Carr (Carr, 1964) well connected the concept of realism in this regard 'Its (realism) genuine assumptions are grounded in the ideological requirements of the social practice; state power contains varied ideological, economic and military components, it is measured and expressed in basic form as the 
nationally established capability of a state to influence international outcomes.'

Hobbes (Peter.J.Steinberger, 2008) the founding father of modern political theory basically emphasized more on civil and religious wars although he wrote at the start of modern age but still we can relate his theories to the contemporary world. His visualization of the world is extraordinarily original and quiet pertinent to modern politics. His foremost apprehension is of societal and political problems and disorder: how and at what cost and in which environment human beings can live together in peace without having any fear of conflicts. His blunt stances were alternatives that can be resulted in a sovereign state as he discovered that society or nation should give their submission to an unaccountable sovereign (a person or group authorized to resolve every single social and political dispute).

As he (Hobbes) firmly believed that in the absence of sovereign power which jells them to peace men's normal condition is a condition of conflict or war: (Malcolm, 2002)

'Whatsoever is consequent to a time of warre, where every man is enemy to every man; same is consequent to the time wherein men live without other security, then what their own strength and their own invention shall furnish them with all. In such conditions, there is no place for industry, because the fruit thereof is uncertain, and consequently no culture of the earth, no navigation nor use of the commodities that may be imported by sea, no commodious building, no instruments of moving, and removing such things as require much force, no knowledge of the face of the earth, no account of time, no arts, no letters no society'.

Hobbe's (Leivas, 2012) basic conclusion was that the human beings can be delivered from the natural condition of war only by the creation of 'an artificial man' a sovereign authority that is 'state'.

The state is the highest form of human relationship logically speaking the terms State and Nation can be used as synonyms, when we denote 'Western nations' or 'Asian nations' or 'African nations', it does not mean nations but States. 'United Nations' is in reality an organization of nation- 
states. In fact every modern state is a Nation State; but there are some important differences between the State and the Nation it is well understood that the four basic elements of state are population, territory, government and sovereignty; a state will lose its existence in the absence of any one of these basic elements whereas, nation cannot be eradicated easily as it is a strong bond of people who have a durable sense of unanimity and common consciousness. Joint territory, common race, common religion, common language, common history, common culture and common political ambitions and goals are the fundamentals which help the formation of a nation. Hence nation is a social, cultural, psychological, responsive and political union. The rudimentary obligation of a nation is the durable bond of emotional unity between its people, it can be strengthened due to several common social and cultural elements. Leo Suryadinata (Suryadinata, 2000) defines Nationalism as 'expression of national feelings'. Citizen hold nationality of a state and it is a political and legal concept whereas nationalism and love for nation does not require nationality or legal documents.

\section{GLOBALIZATION AND THE FADING IDEOLOGICAL BOUNDARIES OF THE CONTEMPORARY STATES}

Undeniably realism provide and is enriched with theories to explain the world politics. It is clear now that as per realism the 'states' are the utmost honored players of realism but advocates of globalization stresses that the authority of states are constantly deteriorating because of the byproducts of globalization like transnational corporations, powerful regional and international institutions and due to the unofficial, un avoidable and un controllable transfer of ideas and Culture. Nation states are compelled to share and bargain their powers as described by Keith Suter (Suter, 2003) with three groups of global actors transnational corporations, international or more accurately intergovernmental organizations such as the United Nations and NGO's. Dr Keith Suter who is among one of the highly influential global futurist and a foreign affairs expert well concluded that: 
'Globalization is the process by which the nation state is eroding as the fundamental unit of world politics.

The term comprises the declining power of national governments and the reduced significance of national boundaries' (Suter, 2003)

To strengthen the territorial boundaries and to unite the nation and to uplift the moral of the states realism lays great importance in solidification of the hard and soft boundaries of 'nation states'. John.T.Rourke (John.T.Rourke, 2007) well explained the link between Nation states and realism 'Realists are likely to seeing humanity as innately divided by national loyalty to countries or some other focus of political identity'. It is a fact that international system of nation states and the nation state itself are coming under fire in a global world although un deniably there are more states in the world particularly after 1989 but most of the new ones are weak and lack complete sovereignty and control.

On one hand, globalization open the doors for a state or nation to accomplish economic prosperity, to spread political freedom and to promote peace while on the other hand, as a result of globalization, states and its citizens face the problems of social fragmentation creating critical vulnerabilities violence and conflicts. Another dreadful result of globalization is economic crisis and all above problems lay important implications on security. Amy Chua, (Chua, 2004) scholar of international relations claimed and emphasized that the cause of most of the ethnic conflicts are 'democracy and globalization'. She emphasized that the unnatural and the negative propaganda of pro-democracy and globalization are main players giving rise to ethnic politics, genocidal violence and economic devastation throughout the developing world. By using the byproducts of globalization that is free and rapid and advance media, capitalism and democracy it is quite easy nowadays to frustrate and spoil the young generations of the developing countries and to damage the cultural fabric which provide them 'identity', 'sovereignty', 'sense of pride 'and 'feeling of ownership' . Culture plays a vital role in grooming and uplifting the nations. Cultural globalization as a powerful tool used by great powers for their fight for supremacy in a way globalization is just 
another situation for everlasting struggle for hegemony (Gilpin, 2000, Mearsheimer,2003).

It is a fact that the consequence benefits of globalization are different for different countries weaker nation are being used by the strong nations with the help of this attractive tool. As per Thucydides the strong do what they have power to do and the weak accept what they have to accept. In this respect the role of governments are very important; proper and timely implementation of rules and regulations can help the states to achieve the political and economic goals and to achieve these targets the influence of civilization through proper use of media and through other tools can be achieved.

\section{NATIONALISM AS A TOOL TO INFER CULTURAL HEGEMONY}

Nationalism is the spirit of solidifying people of a nation and praising, adhering and promoting its culture. In a globalized world the massive flow of people, capital, rituals, customs, ideas, technology and homogenization of culture has placed the role of contemporary nationalism into question. Globalization and nationalism have had a principally existing clash due to the immense upsurge of globalization in the 21 st century. Nationalism and realism are the theories focusing more on strengthening the nation state system and favoring particularistic theories at their most fundamental level. The massive tsunami of globalization has put into question what it means to be a citizen of a state, whether or not state's still have distinguishing cultures, and to what extent distinct national borders are still relevant.

John J. Mearsheimer (II)1, 2006) studied the relation between realism and nationalism:

'I try to show that there are significant similarities between nationalism and realism at the initial level. Both theories are particularistic, not universalistic, and each privileges two key ideas: the state and survival. To clarify this resemblance between nationalism and realism, I contrast them with liberalism and Marxism. Second, I attempt to show that nationalism 
and power politics are actually intertwined phenomena that affect each other in substantial ways, and this interaction has played a central role in fabricating the modern state system. Third, nationalism has had a deep effect on various aspects of international politics that are central to the realist enterprise'.

As globalization emphasizes on the homogenization of cultures, deterritorialization, diffusion, lingua franca, borders liquidation hence it is assumed that it has diminished the role of nationalism and national identity as a whole. "Globalization is the anti-thesis of nationalism as it suggests that there are no boundaries [and] just one globe" (Godfrey, 2008). Anneke J. Rummens (1993) defined identity as the distinctive character belonging to any given individual, or shared by all members of a particular social category or group'.

Most of the western countries and America are mainly responsible for imposing soft power to the third world nations to achieve their targets; globalization is being used as a tool to extend the unseen boundaries of powerful nations Natalie Sabanadze (Sabanadze, 2010) well described this urge with these words: 'The interests of security and political competition explain why forces of nationalism engage and often promote globalization, which they see not as threatening but rather as furthering their objectives'.

Globalization has activated the tendency of migration hence the increased flow of people have resulted in the diffusion of cultural trends therefore the prominence and singularity of different cultures have been eroded. Whereas the studies of realism and nationalism supported the idea that nation is a huge community of individuals who share, practice and are loyal to the same culture. The group members assume that the people of the nation have a strong bond between them although nation is an "imagined community" as no person knows all the other members. It is not possible that every individual of a nation knows all or maximum number of his or her fellow nationals, but they undoubtedly attached themselves and with them and has certain loyalties to them because they are all members of the same nation. Now we are witnessing more varied mixed cultures within countries permitting for more globalized sociocultural 
arrangements. This overall scenario is responsible in undermining the nationalist ideology. in the words of Arjun Appadurai, "have eroded the capabilities of many states to monopolize loyalties, and intensified fears of cultural and physical survival' .In addition to this increasing influence of MNC's and supranational and regional organizations are also responsible for diminishing and eroding the importance of nationalism and nation states in the international system. Nationalism focuses on the ideology that the world is naturally separated into a multitude of distinct, different and dissimilar nations. Changing concepts of citizenship and the diminished sentiments of association to one's country are responsible for lessening the spirit of nationalism.

Roy Starrs (Starrs, 2013)describes nationalism and globalization in Asian context in a research paper published by Rout ledge 'Asian Nationalism in age of Globalization' he discussed a very sensitive point that 'Nationalism is often regarded as the force which liberated Asia from the Western imperial domination and globalization is just as often regarded as the force which threatens to restore that domination'. The author explained his views through different examples he also quoted the sentiments of Bob Catley by describing the clear intention of US to spread liberalizaton policies throughout the globe through the engine of globalization to maximize the US political, economic and social benefits and interests. Steger (2003) representing this view, explains the income of globalization by saying "the income of the rich countries will grow richer and the poor countries will increase poverty and the case is continues until now".

\section{CONCLUSION}

In spite of the fact that the today's globalized world stresses to expand the social interconnectedness across the cultures but it cannot weaken the importance of a state's indigenous Culture and the spirit of Nationalism. Cultural values play vital role in lasting influence on society and in keeping the spirit of Nationalism high. Nationalism is an ideology that keeps active the conceptions of self-determination, self-reliance, and freedom. 
Although, historically it is an established fact that cultural change is a continuous process but the natural change adds more flavors and colors and people accept it without having any fear whereas imposed and and planned changes actually are the efforts to denounce the importance of a specific nation, class, language, race or religion and this cultural imperialism cannot be accepted. Previously colonization and military expansion were the main and significant forces which contributed to cultural change. Now rapid, and effective communication and transport services are the key factors that are contributing and are activating the cultural changes however it is necessary and inevitable to realize that these changes can not undermine the importance of unity and harmony. Joseph Nye in his book 'Globalization and realism' accepted and endorse the fact that USA intentionally promoted the cultural values that in larger context supported its foreign, economic and defense policies he accepted the fact that if a country promotes and represent the values that other nation wants to follow then it will cost less to lead.

It is a fact that the relative benefits of globalization are dissimilar for different countries weaker nation are being used by the strong nations with the help of this attractive tool .As per Thucydides the strong do what they have power to do and the weak accept what they have to accept. In this respect the role of governments are very important proper and timely implementation of rules and regulations can help the states to achieve the political and economic goals and to achieve these targets the influence of civilization through proper use of media and through other tools can be achieved. The classical approach to the study of international relations, realism consider domestic politics separated from the international system as according to them state interest should be the only prioritize aim of the government. Realists focus on nation state and the logical, foremost, ultimate, premium and just desire to advance national interests at any cost. 


\section{REFERENCES}

Albrow, M., King E. (1990). globalization, knowledge and society. UK: Sage Publications.

Appadurai, A. (2010). Disjuncture and Difference in the Global Cultural Economy. In Theory culture and society, 295-310.

Beck, U. (2000). What is Globalization? Cambridge: Polity Press.

Cancilini, G. (2014). Imagined globalization. Durham, NC: Duke University Press.

Carr, E. (1964). The Harmony of Interests. In E.H.Carr, The twenty years Crisis. New York NY: Harper and Row.

Chua, A. (2004). World on fire.

Freidman, J. (july, 2014). 391Indigenous Struggles and the Discreet Charm of the Bourgeoisie . San Diego: University of Califonia.

Giddens, A. (1991). the consequences of modernity. Cambridge: Polity Press.

globalization, nation states and global governance. (n.d.). Retrieved from https://webcache.googleusercontent.com/search?q=cache:aIsCX31BYYAJ :https://www.springer.com/cda/content/document/cda_downloaddocument 19781461415503-c1.pdf\%3FSGWID\%3D0-0-45-1261841$\mathrm{p} 174193172+\& \mathrm{~cd}=1 \& \mathrm{hl}=\mathrm{en} \& \mathrm{ct}=\mathrm{clnk} \& \mathrm{gl}=\mathrm{pk}$

Gullen, M. F. (2001). IS GLOBALIZATION CIVILIZING, DESTRUCTIVE. $\quad$ Retrieved from https://pdfs.semanticscholar.org/e22f/ecbbe1f18dbabcfdad94b7b414e7abf $\underline{6 c c c 3 . p d f}$

Hirst, P., \& Thompson, G. (1996). Globalization in Question. Cambridge: Polity Press. 
Mearsheimer, Jhon J. Interviewer (2006). Conversations in International Relations. Retrieved from https://journals.sagepub.com/doi/abs/10.1177/0047117806063851

Rourke. John.T. (2007). International politics on the world stage. Mc Grew Hill.

Kaldore, M. (1999). Cosmopolitanism vs. Nationalism: The New Divide? . Cambridge: Polity Press.

Langhorne, R. (2001). The coming of globalization: Its Evolution and Contemporary Consequences Palgrave McMillan.

Leivas, C. R. (2012). The science of the preservation of state: Hobbes and the question of dissolution and maintanence of modern political state. In The science of the preservation of the State . veritas.

Malcolm, N. (2002). Aspects of Hobbes. Clarendon Press Publication.

Peter.J.Steinberger. (2008). Hobbes, Rousseau and the Modern Conception of the State. The Journal of Politics, 70(3), 595-611.

Robertson, R. (1992). Globalization: social theory and global culture. London: sage Publications.

Sabanadze, N. (2010). Globalization and Nationalism: The Cases of Georgia and the Basque Country. Central European University Press.

Starrs, R. (2013). Asian Nationalism in age of Globalization. Routledge.

Steger, M. b. (2007). What is global studies? theory and practice. Routledge.

Suryadinata, L. (2000). Nationalism and Globalization: East and West' . Institute of South east asian studies. 
Suter, K. (2003). Global Order and disorder. Praeger.

Unesco.org. (2000, September). Retrieved from Social and Human Sciences: $\quad$ http://www.unesco.org/new/en/social-and-humansciences/themes/international-migration/glossary/globalisation/

Waters, M. (1995). Globalization : Key ideas. Routledge. 